\title{
Study of thermal shock resistance of flame sprayed coatings manufactured to protect molds used in glass containers industry
}

\author{
Estudio de la resistencia al choque térmico de recubrimientos manufacturados \\ por proyección térmica de llama para proteger moldes usados en la industria \\ de envases de vidrio
}

\author{
David Franco $^{1} \quad$ Fabio Vargas $^{1} \quad$ Esperanza López ${ }^{1}$
}

Recibido 24 de abril de 2015, aceptado 11 de septiembre de 2015

Received: April 24, $2015 \quad$ Accepted: September 11, 2015

\begin{abstract}
Molds used in glass manufacturing are subjected to continuous heating and cooling cycles, which result in their premature failure by thermal fatigue. In order to protect these molds a nickel alloy (Eutectic Castolin CPM $1205^{\mathrm{TM}}$ ) was deposited as bond coat by flame spraying onto compacted graphite iron substrates and then, $\mathrm{Al}_{2} \mathrm{O}_{3}-40$ wt. $\% \mathrm{TiO}_{2}, \mathrm{ZrO}_{2}-36$ wt. $\% \mathrm{Al}_{2} \mathrm{O}_{3}$ and $\mathrm{Al}_{2} \mathrm{O}_{3}$, as well as a Ni-WC cermet, were sprayed as a top coatings using super oxidized and slightly oxidized flames. The effect of the flame type and the thickness of coatings on thermal shock resistance were evaluated. The results obtained indicate that coatings of Ni-WC sprayed from Eutectic Castolin $10112^{\mathrm{TM}}$ powders using a slightly oxidized flame, and $\mathrm{ZrO}_{2}-\mathrm{Al}_{2} \mathrm{O}_{3}$ coatings manufactured from nano-agglomerated Eutectic Castolin $25088^{\mathrm{TM}}$ powders with an super oxidized flame showed the best performances. The nature of Ni-WC cermets allowed increasing the thermal shock resistance due to the thermo-elastic behavior of nickel matrix and the arrest crack effect characteristic of composite materials. Likewise, in $\mathrm{ZrO}_{2}-\mathrm{Al}_{2} \mathrm{O}_{3}$ coatings, the bimodal microstructure that this kind of coatings shows contributed to increase the thermal shock resistance. The better performances of both coatings were obtained with a porosity level between $20 \%$ and $40 \%$.
\end{abstract}

Keywords: Flame thermal spaying, nickel alloy bond coat, cermet top coating, ceramic top coating, thermal shock resistance.

\section{RESUMEN}

Los moldes usados en la manufactura de vidrio están sujetos a continuos ciclos de calentamiento y enfriamiento, lo que resulta en fallas prematuras por fatiga térmica. Con la idea de proteger estos moldes, una aleación de níquel (Eutectic Castolin CPM 1205TM) fue depositada por proyección térmica de llama bajo condiciones de combustión neutras como capa base sobre sustratos de hierro gris. Posteriormente, con la misma técnica de proyección, y bajo condiciones oxidantes y superoxidantes, fueron aplicados como recubrimientos superiores polvos de: $\mathrm{Al}_{2} \mathrm{O}_{3}-40 \mathrm{wt}$. \% $\mathrm{TiO}_{2}, \mathrm{ZrO}_{2}-36 \mathrm{wt}$. $\% \mathrm{Al}_{2} \mathrm{O}_{3}$ y $\mathrm{Al}_{2} \mathrm{O}_{3}$, así como el cermet: $\mathrm{Ni}-\mathrm{WC}$, esto con el fin de evaluar la influencia del tipo de llama y el tipo de recubrimiento sobre la resistencia al choque térmico. Los resultados indican que los recubrimientos de Ni-WC manufacturados desde polvos de Eutectic Castolin $10112^{T M}$ en condiciones oxidantes, así como recubrimientos de $\mathrm{ZrO}_{2}-\mathrm{Al}_{2} \mathrm{O}_{3}$ fabricados desde polvos nanoaglomerados de Eutectic Castolin $25088^{T M}$ en condiciones superoxidantes, mostraron los mejores desempeños. La naturaleza del Ni-WC permitió incrementar la resistencia al choque térmico debido al comportamiento termoelástico de la matriz de níquel, así como a la capacidad de contrarrestar las grietas característica de los materiales compuestos. Por su lado, para los recubrimientos de $\mathrm{ZrO}_{2}-\mathrm{Al}_{2} \mathrm{O}_{3}$, la microestructura bimodal que esta

\footnotetext{
1 Grupo de Investigaciones Pirometalúrgicas y de Materiales (GIPIMME). Universidad de Antioquia. Postal Code: 050010. Medellín, Colombia.E-mail: idavid.franco@udea.edu.co; fabio.galvis@udea.edu.co; esperanza.lopez@udea.edu.co
} 
clase de materiales muestra fue la que contribuyó a incrementar la resistencia al choque térmico. Por último, es de notar que los mejores desempeños para ambos tipos de recubrimientos fueron obtenidos en niveles de porosidad entre $20 \%$ y $40 \%$.

Palabras clave: Proyección térmica de llama, capa base de Ni, capa superior cerámica, cermet, resistencia al choque térmico.

\section{INTRODUCTION}

Molds used in glass production are made of compacted graphite iron, which provides better resistance to thermal fatigue and abrasion wear than those with flakes and nodules of graphite [1]. These molds are subjected to constant heating and cooling cycles, generating cracks by thermal fatigue [1-2]. Studies previously carried out by others researchers indicated that the thermal fatigue resistance of pig iron ingot molds increases when a bond coat and a ceramic top coat are deposited onto their surface by thermal spraying processes. $\mathrm{NiAl}, \mathrm{NiCr}$ and $\mathrm{NiCrAl}$ have been deposited as bond coat, withstanding over 5000 cycles of thermal shocks from $1100{ }^{\circ} \mathrm{C}$ to room temperature cooling with an air jet, while $\mathrm{ZrO}_{2}-8$ wt. $\% \mathrm{Y}_{2} \mathrm{O}_{3}, \mathrm{ZrO}_{2}-24$ wt. $\% \mathrm{MgO}$, and $\mathrm{Al}_{2} \mathrm{O}_{3}$ have been sprayed as ceramic top coats by plasma and flame spraying processes, which withstood between 5 and 600 cycles depending of spraying parameters and chemical composition of coatings evaluated [2].

On the other hand, the thermal shock resistance of SUS 304 stainless steel substrates coated by plasma spraying process using NiCoCrAlY as bond coat, and mixtures of $\mathrm{Al}_{2} \mathrm{O}_{3}, \mathrm{ZrO}_{2}$ stabilized with $8 \mathrm{wt} . \%$ $\mathrm{Y}_{2} \mathrm{O}_{3}$, and with particles of $\mathrm{SiC}$ in submicrometrical/ nanometrical size, as top coats was studied [3]. The thermal shock resistance was produced from $800^{\circ} \mathrm{C}$ and $1000{ }^{\circ} \mathrm{C}$ to room temperature using water to $20^{\circ} \mathrm{C}$. The thermal shock resistance was established as the number of cycles which the spallation in the sample reached the $20 \%$ of its area. The addition of submicrometrical and nanometrical $\mathrm{SiC}$ improved the thermal shock resistance from $1000{ }^{\circ} \mathrm{C}$ of these coatings reaching 83 cycles [3]. Additionally, thermal shock resistance of both: $\mathrm{Al}_{2} \mathrm{O}_{3}-\mathrm{TiO}_{2}-\mathrm{ZrO}_{2}-\mathrm{CeO}_{2}$ and $\mathrm{Al}_{2} \mathrm{O}_{3}-13 \%$ wt. $\% \mathrm{TiO}_{2}$ coatings manufactured by plasma spray onto carbon steel substrates from nano-agglomerated, and from fused and crushed micrometrical particles respectively, was studied. The tests were carried out by heating the coatings to $650{ }^{\circ} \mathrm{C}$ and $850{ }^{\circ} \mathrm{C}$ during $10 \mathrm{~min}$ and then cooling them using water to room temperature. The results indicate that coatings sprayed from nano-agglomerated particles have higher resistance than those manufactured from fused and crushed powders, reaching 69 cycles at $650^{\circ} \mathrm{C}$ and 6 cycles at $850^{\circ} \mathrm{C}$ for the nano-agglometared particles, and 42 cycles at $650{ }^{\circ} \mathrm{C}$ and 3 cycles at $850{ }^{\circ} \mathrm{C}$ for the fushed and crushed micrometrical powders. In this case the thermal shock resistance was established as the cycle number which a visible failure area was detected [4].

In this research flake graphite cast iron substrates used in molds to manufacture glass containers by Owens-Illinois Inc. (O-I) Colombian Plants, were coated by flame spraying process using an Eutectic Castolin Super-Jet Eutalloy ${ }^{\mathrm{TM}}$ gun for Ni-Si bond coats and cermets of Ni-WC as top coats, as well as an Eutectic Castolin Terodyn $2000^{\mathrm{TM}}$ for spraying $\mathrm{Al}_{2} \mathrm{O}_{3}, \mathrm{Al}_{2} \mathrm{O}_{3}-\mathrm{TiO}_{2}$, and $\mathrm{ZrO}_{2}-\mathrm{Al}_{2} \mathrm{O}_{3}$ as a top coats. The thermal shock resistance was evaluated by fast cooling from $650{ }^{\circ} \mathrm{C}$ and $1100{ }^{\circ} \mathrm{C}$ to room temperature using water.

\section{EXPERIMENTAL METHODS}

\section{Substrates, feedstock powders and coatings manufacturing}

The microstructural characterization of substrates was carried out according to ASTM A247-10 standard [5]. Subsequently, cylindrical substrates of $20 \mathrm{~mm}$ in diameter and $10 \mathrm{~mm}$ in thickness were manufactured from discarded graphite cast irons molds. The surface of cross section substrates were grit blasted using a corundum particles jet and sonicated in an alcohol bath in order to provide the roughness $(\operatorname{Ra} \approx 5 \mu \mathrm{m})$ and cleanness necessary to obtain a good adhesion of bond coat particles. The chemical composition, size particle distribution and morphology of feedstock powders were determined by Wave-Length X Ray Fluorescence (WD-XRF), Laser Diffraction and Scanning Electron Microscopy (SEM) were used to determine the 
chemical composition, size particle distribution and morphology of feed stock powders. For WD-XRF analysis an ARL OPTIM'X spectrometer was used, while a Master Sizer 2000 equipment and a JEOL JSM 6490 LV microscope were used to evaluate the distribution size particle and the morphology of powders respectively.

The Ni-Si Eutectic Castolin CPM $1205^{\mathrm{TM}}$ powder was sprayed as bond coat by flame spraying using an Eutectic Castolin Super-Jet Eutalloy ${ }^{\mathrm{TM}}$ torch with a slightly oxidized flame produced from a mixture of $11.9 \mathrm{~L} / \mathrm{min}$ of oxygen and $7.3 \mathrm{~L} / \mathrm{min}$ of acetylene. The spray distance was $25 \mathrm{~mm}$, the relative speed between the torch and the substrates was $0.44 \mathrm{~cm} / \mathrm{s}$ and the rotational speed of substrates was $116 \mathrm{rpm}$. Six passes of the torch in front of the substrates were carried out in order to preheat them with the oxyacetylene flame and then, nine spraying passes at a rate of $77 \pm 2 \mathrm{~g} / \mathrm{min}$ were deposited obtaining thicknesses in the bond coats of $300 \pm 20 \mu \mathrm{m}$.

The $\mathrm{Al}_{2} \mathrm{O}_{3}$ Sulzer Metco $105 \mathrm{SPF}^{\mathrm{TM}}, \mathrm{Al}_{2} \mathrm{O}_{3}-40$ wt. $\% \mathrm{TiO}_{2}$ Saint Gobin $\mathrm{SG}-109^{\mathrm{TM}}$ and $\mathrm{ZrO}_{2} \approx 35.7$ wt. $\% \mathrm{Al}_{2} \mathrm{O}_{3}$ Eutectic Castolin $25088^{\mathrm{TM}}$ powders were sprayed by flame spraying process with an Eutectic Castolin Terodyn $2000^{\mathrm{TM}}$ torch in order to deposited top coatings on the Ni-Si bond coats. The flame parameters were determined from previous studies and simulations were carried out using the Jets and Powders software. In order to determine the flame effect on the structure of coatings, slightly oxidized and a super oxidized flames were used to spraying the top coats from a mixtures of 38.6/22.5 $\mathrm{L} / \mathrm{min}$ of oxygen/acetylene and 96.1/22.5 L/min oxygen/acetylene respectively, and then the effect on the porosities on the thermal shock resistance of coatings was evaluated.

The slightly oxidized flame used to manufacture bond and top coatings was obtained from an oxygen and acetylene volumetric ratio of 1.7 where the higher temperature of the flame is achieved, while the super oxidized flame was produced from a volumetric ratio of oxygen and acetylene of 4.3 in order to obtain a longer primary zone in the flame, getting a higher time of residence of feedstock powders in the hottest zone of flame [6-7].

The spraying parameters were determined from previous tests. The spray distance was $90 \mathrm{~mm}$, the relative speed between the torch and the substrates was $0.72 \mathrm{~cm} / \mathrm{s}$ and the rotational speed of substrates was $116 \mathrm{rpm}$. In order to evaluate the effect of top coats thickness on the thermal shock resistance, 5, 7 and 10 spraying passes were applied for each type of flame seeking to obtain coatings with low $(150 \pm 20 \mu \mathrm{m})$, medium $(200 \pm 20 \mu \mathrm{m})$ and high $(280 \pm 20 \mu \mathrm{m})$ thicknesses.

The Ni-WC cermet Eutectic Castolin $10112^{\mathrm{TM}}$ was sprayed as top coat by flame spraying using an Eutectic Castolin Super-Jet Eutalloy ${ }^{\mathrm{TM}}$ torch, using an slightly oxidized and a super oxidized flames from a mixtures of $11.9 / 7.3 \mathrm{~L} / \mathrm{min}$ of oxygen/acetylene and 18.8/7.3 L/min oxygen/ acetylene respectively. The spray distance was 27 $\mathrm{mm}$, the relative speed between the torch and the substrates was $0.44 \mathrm{~cm} / \mathrm{s}$ and the rotational speed of substrates was $116 \mathrm{rpm}$. For these coatings, 6, 10 and 13 spraying passes were applied for each type of flame, seeking to obtain the same ranges of thicknesses aforementioned (low: $150 \pm 20 \mu \mathrm{m}$, medium: $200 \pm 20 \mu \mathrm{m}$ and high: $280 \pm 20 \mu \mathrm{m}$ ), and then, the effect of top coats thickness on the thermal shock resistance was evaluated.

In total, 96 samples were projected and split in: 24 samples were used for thermal shock tests at $1100^{\circ} \mathrm{C}$, 24 samples for thermal shock tests at $650{ }^{\circ} \mathrm{C}, 24$ samples to evaluate porosity and thickness, and the 24 samples remaining were manufactured as back up. All conditions of projections are summarized in Table 1.

Finally, the factor: "Powder", with its levels: $\mathrm{Al}_{2} \mathrm{O}_{3}$ Sulzer Metco $105 \mathrm{SPF}^{\mathrm{TM}}, \mathrm{Al}_{2} \mathrm{O}_{3}-40$ wt.\% $\mathrm{TiO}_{2}$ Saint Gobin SG-109 ${ }^{\mathrm{TM}}, \mathrm{ZrO}_{2} \approx 35.7$ wt. $\% \mathrm{Al}_{2} \mathrm{O}_{3}$ Eutectic Castolin $25088^{\mathrm{TM}}$ and the Ni-WC cermet Eutectic Castolin $10112^{\mathrm{TM}}$; the factor: "Flame", with its levels: slightly oxidized and super oxidized, as well as the factor: "Thickness", with its levels: low, medium and high, constitute a factorial design of experiments (DOE) with 3 factors and 24 runs, whose main goal is to evaluate the effect of these variables on the thermal shock resistance of coatings simultaneously. All features of DOE are summarized in Table 2.

\section{Thermal shock tests and structural characterization of coatings}

The structure of coatings was characterized by SEM and optical microscopy analysis image on their cross section through JEOL JSM 6490 LV and Olympus 
Table 1. Spraying conditions used to manufacture the coatings.

\begin{tabular}{|c|c|c|c|c|c|}
\hline \multirow[b]{2}{*}{ Variable } & \multicolumn{2}{|c|}{ Ceramic Top Coatings } & \multicolumn{2}{|c|}{ Cermet Top Coatings } & \multirow{2}{*}{$\begin{array}{c}\text { Ni-Si } \\
\text { Bond Coatings } \\
\text { Neutral }\end{array}$} \\
\hline & $\begin{array}{c}\text { Super } \\
\text { Oxidized } \\
\text { Flame } \\
\end{array}$ & $\begin{array}{c}\text { Slightly } \\
\text { Oxdized } \\
\text { Flame }\end{array}$ & $\begin{array}{c}\text { Super } \\
\text { Oxidized } \\
\text { Flame } \\
\end{array}$ & $\begin{array}{c}\text { Slightly } \\
\text { Oxidized } \\
\text { Flame }\end{array}$ & \\
\hline $\mathrm{O}_{2}$ Flow [L/min] & 96.1 & 38.6 & 18.8 & 11.9 & 11.9 \\
\hline $\mathrm{C}_{2} \mathrm{H}_{2}$ Flow $[\mathrm{L} / \mathrm{min}]$ & 22.5 & 22.5 & 7.3 & 7.3 & 7.3 \\
\hline $\mathrm{O}_{2}$ Pressure[psi] & \multicolumn{2}{|c|}{50} & \multicolumn{2}{|c|}{50} & 50 \\
\hline $\mathrm{C}_{2} \mathrm{H}_{2}$ Pressure [psi] & \multicolumn{2}{|c|}{12} & \multicolumn{2}{|c|}{10} & 10 \\
\hline Powder Flow[g/min] & \multicolumn{2}{|c|}{$12 \pm 1$} & \multicolumn{2}{|c|}{$60 \pm 1$} & $77 \pm 1$ \\
\hline Pre - Heating Cycles & \multicolumn{2}{|c|}{3} & \multicolumn{2}{|c|}{6} & 6 \\
\hline Projection Cycles & \multicolumn{2}{|c|}{$5,7 \& 10$} & \multicolumn{2}{|c|}{$6,10 \& 13$} & 9 \\
\hline Post - Heating Cyles & \multicolumn{2}{|c|}{-------- } & \multicolumn{2}{|c|}{9} & 16 \\
\hline Spray Distance $[\mathrm{mm}]$ & \multicolumn{2}{|c|}{90} & \multicolumn{2}{|c|}{27} & 25 \\
\hline Rotojet & \multicolumn{2}{|c|}{ RPA3 } & \multicolumn{2}{|c|}{-------- } & ------- \\
\hline Torch & \multicolumn{2}{|c|}{ Terodyn $2000^{\mathrm{TM}}$} & \multicolumn{2}{|c|}{ Super-Jet Eutalloy ${ }^{\mathrm{TM}}$} & Super-Jet Eutalloy ${ }^{\mathrm{TM}}$ \\
\hline
\end{tabular}

Table 2. Design of experiments (DOE) details.

\begin{tabular}{|c|c|c|}
\hline Powder & Flame & Thickness \\
\hline \multirow{3}{*}{$\mathrm{Al}_{2} \mathrm{O}_{3}-\mathrm{TiO}_{2} 40$ wt. $\%$} & \multirow{3}{*}{$\begin{array}{l}\text { Super Oxidized } \\
\text { Flame }\end{array}$} & Low \\
\hline & & Medium \\
\hline & & High \\
\hline \multirow{3}{*}{$\begin{array}{l}\text { Saint - Gobin } \\
\text { SG-109 } 109^{\mathrm{TM}}\end{array}$} & \multirow{3}{*}{$\begin{array}{l}\text { Slightly Oxidized } \\
\text { Flame }\end{array}$} & Low \\
\hline & & Medium \\
\hline & & High \\
\hline \multirow{6}{*}{$\begin{array}{c}\mathrm{Al}_{2} \mathrm{O}_{3} \\
\text { Sulzer Metco } \\
105 \mathrm{SFP}^{\mathrm{TM}}\end{array}$} & \multirow{3}{*}{$\begin{array}{l}\text { Super Oxidized } \\
\text { Flame }\end{array}$} & Low \\
\hline & & Medium \\
\hline & & High \\
\hline & \multirow{3}{*}{$\begin{array}{l}\text { Slightly Oxidized } \\
\text { Flame }\end{array}$} & Low \\
\hline & & Medium \\
\hline & & High \\
\hline \multirow{3}{*}{$\begin{array}{c}\mathrm{ZrO}_{2}-\mathrm{Al}_{2} \mathrm{O}_{3} \approx 35.7 \\
\text { wt. \% }\end{array}$} & \multirow{3}{*}{$\begin{array}{l}\text { Super Oxidized } \\
\text { Flame }\end{array}$} & Low \\
\hline & & Medium \\
\hline & & High \\
\hline \multirow{3}{*}{$\begin{array}{c}\text { Eutectic Castolin } \\
25088^{\mathrm{TM}}\end{array}$} & \multirow{3}{*}{$\begin{array}{l}\text { Slightly Oxidized } \\
\text { Flame }\end{array}$} & Low \\
\hline & & Medium \\
\hline & & High \\
\hline \multirow{6}{*}{$\begin{array}{c}\text { Eutectic Castolin } \\
10112^{\mathrm{TM}}\end{array}$} & \multirow{3}{*}{$\begin{array}{l}\text { Super Oxidized } \\
\text { Flame }\end{array}$} & Low \\
\hline & & Medium \\
\hline & & High \\
\hline & \multirow{3}{*}{$\begin{array}{l}\text { Slightly Oxidized } \\
\text { Flame }\end{array}$} & Low \\
\hline & & Medium \\
\hline & & High \\
\hline
\end{tabular}

BX41 respectively, according to ASTM E1920 and ASTM E2109 standards [8-9]. For its part, the thermal shock resistance of coatings was evaluated using two heating conditions, which were: 1$) 650{ }^{\circ} \mathrm{C}$ during 10 minutes, and 2) $1100{ }^{\circ} \mathrm{C}$ during 5 minutes. Then, the samples were cooled using water at room temperature, as it is shown in Figure 1. Each sample was evaluated after each cycle using a stereographic microscope in order to identify cracks or detachment failures and then the thermal shock resistance of coatings was established as the cycle number in which a visible failure was detected. It is important to mention that the operating temperature average of the molds used in the manufacture of glass containers is between $600{ }^{\circ} \mathrm{C}$ and $700{ }^{\circ} \mathrm{C}$, and for this reason the temperature of $650{ }^{\circ} \mathrm{C}$ was chosen [10].

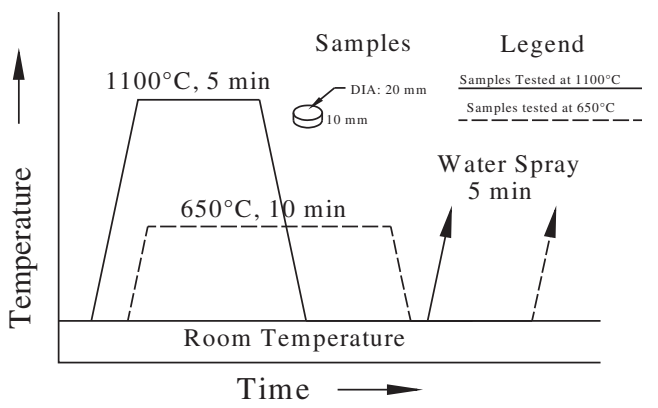

Figure 1. Curves of temperature used in thermal shock tests.

\section{RESULTS AND DISCUSSION}

\section{Raw materials characterization}

The results of micro-structural characterizations realized to substrates indicate that these are constituted by graphite flakes type D randomly dispersed inside a dendritic matrix.

Eutectic Castolin CPM $1205^{\mathrm{TM}}$ used to manufacture the bond coatings consists mainly of $\mathrm{Ni}(97.62 \mathrm{wt} . \%)$ and $\mathrm{Si}(1.79 \mathrm{wt} . \%)$, and its morphology is rounded. Regarding chemical and physical characterization 
of powders used as top coatings, the results indicate that Sulzer-Metco $105 \mathrm{SPF}^{\mathrm{TM}}$ powder is constituted by $\mathrm{Al}_{2} \mathrm{O}_{3}\left(99.71 \pm 0.05\right.$ wt. \%) and $\mathrm{SiO}_{2}(0.174 \pm$ 0.01 wt. \%), with a distribution size particle between $\mathrm{d}_{10}=6.0 \mu \mathrm{m}$ and $\mathrm{d}_{90}=25.5 \mu \mathrm{m}$, and its morphology is irregular. The powder Saint Gobin $\mathrm{SG}-109^{\mathrm{TM}}$ is a blend of $\mathrm{Al}_{2} \mathrm{O}_{3}\left(55.19 \pm 0.25\right.$ wt. \%) and $\mathrm{TiO}_{2}(43.14$ \pm 0.25 wt. \%), with a distribution size particle between $\mathrm{d}_{10}=8.8 \mu \mathrm{m}$ and $\mathrm{d}_{90}=22.3 \mu \mathrm{m}$, and its morphology is irregular. A mixture of $\mathrm{ZrO}_{2}(59.72 \pm 0.20 \mathrm{wt}$ \% \%) and $\mathrm{Al}_{2} \mathrm{O}_{3}(35.70 \pm 0.20$ wt. \%) was identified in Eutectic Castolin $25088^{\mathrm{TM}}$ powder, its shape is spherical and it is constituted by agglomerated nanometrical particles. On the other hand, the Eutectic Castolin $10112^{\mathrm{TM}}$ powder is a cermet constituted by WC $(60$ wt. \%) and a Ni-Cr-B-Si-Fe alloy (40 wt. \%), whose morphology is a mixture of rounded particles of $\mathrm{Ni}$ alloy, and irregular shape particles for WC.

\section{Structure of coatings}

The structural analysis of all samples indicates that bond coats are well adhered to the substrates and a good cohesion between the bonds and top coats were produced (Figure 2). Additionally, the thicknesses of all bond coats manufactured were $300 \pm 20 \mu \mathrm{m}$, and the thicknesses of top coatings obtained were: low $(139 \pm 4 \mu \mathrm{m})$, medium $(198 \pm 6 \mu \mathrm{m})$ and high $(280 \pm 9$ $\mu \mathrm{m})$. For its part, in Table 3 are available the results of porosity obtained by image analysis, as well as the results of thermal shock resistance evaluated through water quenching method using the Figure 1 temperature conditions. These results were obtained according with the DOE conditions listed in Table 2, and in general both, the porosity and the thermal shock resistance of top coats varied with the feedstock powders, with the thickness and with the flame type.

\section{Thermal shock resistance}

The results of thermal shock tests carried out with fast cooling from $650{ }^{\circ} \mathrm{C}$ indicate that all samples withstood 100 cycles of heating/cooling without evidence of cracks, disbonding or cohesion failures, and due to these samples did not fail, these same samples were exposed to thermal shock tests from $1100{ }^{\circ} \mathrm{C}$ to room temperature obtaining the cycles number before failure shown in Table 3 .

Table 3. Results of DOE.

\begin{tabular}{|c|c|c|c|c|c|}
\hline Powder & Flame & Thickness & $\begin{array}{c}\text { Failure at } \\
650^{\circ} \mathrm{C} \& \\
1100^{\circ} \mathrm{C} \\
\text { [\# of Cycles] }\end{array}$ & $\begin{array}{c}\text { Failure at } \\
1100{ }^{\circ} \mathrm{C} \\
{[\# \text { of Cycles] }}\end{array}$ & $\begin{array}{c}\text { Porosity } \\
{[\%]}\end{array}$ \\
\hline \multirow{3}{*}{$\mathrm{Al}_{2} \mathrm{O}_{3}-\mathrm{TiO}_{2} 40$ wt. $\%$} & \multirow{3}{*}{$\begin{array}{c}\text { Super Oxidized } \\
\text { Flame }\end{array}$} & Low & 3 & 2 & $16.51 \pm 4.16$ \\
\hline & & Medium & 2 & 2 & $10.69 \pm 2.09$ \\
\hline & & High & 2 & 2 & $5.87 \pm 1.15$ \\
\hline \multirow{3}{*}{$\begin{array}{l}\text { Saint Gobin } \\
\text { SG-109 }\end{array}$} & \multirow{3}{*}{$\begin{array}{c}\text { Slightly Oxidized } \\
\text { Flame }\end{array}$} & Low & 2 & 3 & $11.53 \pm 7.98$ \\
\hline & & Medium & 3 & 2 & $15.13 \pm 1.98$ \\
\hline & & High & 2 & 2 & $15.00 \pm 2.69$ \\
\hline \multirow{6}{*}{$\begin{array}{c}\text { Sulzer Metco } \\
105 \mathrm{SFP}^{\mathrm{TM}}\end{array}$} & \multirow{3}{*}{$\begin{array}{l}\text { Super Oxidized } \\
\text { Flame }\end{array}$} & Low & 2 & 2 & $9.54 \pm 2.07$ \\
\hline & & Medium & 2 & 2 & $10.06 \pm 1.62$ \\
\hline & & High & 2 & 2 & $10.14 \pm 1.58$ \\
\hline & \multirow{3}{*}{$\begin{array}{c}\text { Slightly Oxidized } \\
\text { Flame }\end{array}$} & Low & 2 & 3 & $49.72 \pm 0.86$ \\
\hline & & Medium & 3 & 2 & $44.93 \pm 5.15$ \\
\hline & & High & 3 & 2 & $46.96 \pm 3.78$ \\
\hline \multirow{6}{*}{$\begin{array}{l}\mathrm{ZrO}_{2}-\mathrm{Al}_{2} \mathrm{O}_{3} \approx 35.7 \text { wt. } \% \\
\text { Eutectic Castolin } 25088^{\mathrm{TM}}\end{array}$} & \multirow{3}{*}{$\begin{array}{c}\text { Super Oxidized } \\
\text { Flame }\end{array}$} & Low & 14 & 15 & $17.91 \pm 2.42$ \\
\hline & & Medium & 10 & 15 & $15.46 \pm 2.09$ \\
\hline & & High & 11 & 12 & $19.68 \pm 2.94$ \\
\hline & \multirow{3}{*}{$\begin{array}{c}\text { Slightly Oxidized } \\
\text { Flame }\end{array}$} & Low & 11 & 13 & $34.74 \pm 2.60$ \\
\hline & & Medium & 10 & 12 & $33.85 \pm 3.28$ \\
\hline & & High & 11 & 12 & $30.14 \pm 0.59$ \\
\hline \multirow{6}{*}{ Eutectic Castolin $10112^{\mathrm{TM}}$} & \multirow{3}{*}{$\begin{array}{l}\text { Super Oxidized } \\
\text { Flame }\end{array}$} & Low & 16 & 23 & $28.07 \pm 1.16$ \\
\hline & & Medium & 14 & 23 & $28.09 \pm 1.16$ \\
\hline & & High & 15 & 22 & $31.11 \pm 1.49$ \\
\hline & \multirow{3}{*}{$\begin{array}{l}\text { Slightly Oxidized } \\
\text { Flame }\end{array}$} & Low & 21 & 36 & $38.68 \pm 1.12$ \\
\hline & & Medium & 19 & 35 & $38.52 \pm 0.94$ \\
\hline & & High & 19 & 32 & $38.81 \pm 0.80$ \\
\hline
\end{tabular}



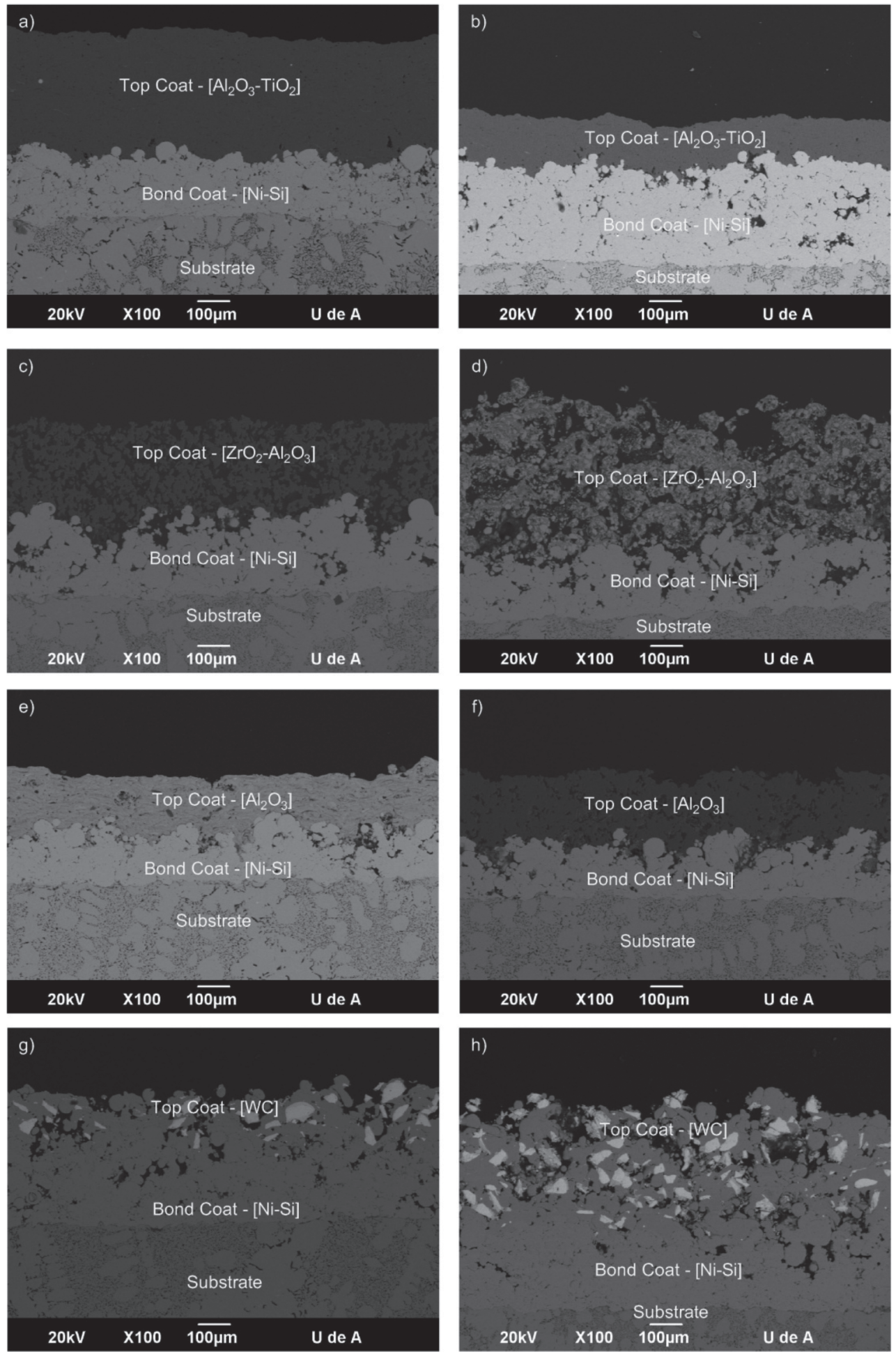

Figure 2. Microstructures obtained during projections. a) $\mathrm{Al}_{2} \mathrm{O}_{3}-\mathrm{TiO}_{2}$ using a super oxidized flame. b) $\mathrm{Al}_{2} \mathrm{O}_{3}$ - $\mathrm{TiO}_{2}$ using a slightly oxidized flame. c) Using a super oxidized flame. d) $\mathrm{ZrO}_{2}-\mathrm{Al}_{2} \mathrm{O}_{3}$ using a slightly oxidized flame. e) $\mathrm{Al}_{2} \mathrm{O}_{3}$ using a super oxidized flame. f) $\mathrm{Al}_{2} \mathrm{O}_{3}$ using a slightly oxidized flame. g) Ni-WC using a super oxidized flame. h) Ni-WC using a slightly oxidized flame. 
Additionally, in Table 3 the thermal shock resistance of coatings tested from $1100^{\circ} \mathrm{C}$ is shown, evidencing a better performance in cermet $\mathrm{Ni}-\mathrm{WC}$ top coatings (between 22 and 36 cycles before failure according to flame type and thickness of coating) and $\mathrm{ZrO}_{2^{-}}$ $\mathrm{Al}_{2} \mathrm{O}_{3}$ top coatings (between 12 and 15 cycles before failure according to flame type and thickness of coating). The good performances of $\mathrm{Ni}-\mathrm{WC}$ and $\mathrm{ZrO}_{2}-\mathrm{Al}_{2} \mathrm{O}_{3}$ is based on the microstructures obtained from the raw materials, since $\mathrm{ZrO}_{2}-\mathrm{Al}_{2} \mathrm{O}_{3}$ powders have nano-agglomerated particles allowing bimodal structures formed by fully molten and semi-molten particles that retain the characteristics and properties of nano-agglomerated powders and then arrest the cracks advance produced during thermal shock tests, and for hence this micro-structure allow to get better resistances [4, 11-14]. On the other hand, the Ni-WC shows behaviors of composite, with a thermo-elastic matrix and ceramic particles that also allow to stop the cracks getting better resistances as well.

Further, the better performance showed by coatings of $\mathrm{Ni}-\mathrm{WC}$ and $\mathrm{ZrO}_{2}-\mathrm{Al}_{2} \mathrm{O}_{3}$ can be related with the structural porosity of top coats, oscillating between $20 \%$ and $40 \%$, range of porosities that seems to be an ideal range for this variable with coatings manufactured from the powders used in this study. According with Girolamo [14] in nanostructured yttria stabilized zirconia (YSZ) coatings, and according with Rangaswamy [15] in 5CaSZ plasma sprayed coatings, porosity values $>20 \%$ increase the thermal shock resistance; however, the optimal porosity depends also of the powder type (chemical composition and its phases). For example coatings of $\mathrm{Al}_{2} \mathrm{O}_{3}$ showed poor performances with porosities $>40 \%$ (those manufactured with a slightly oxidized flame), and $<20 \%$ (those sprayed using a super oxidized flame). On the other hand, coatings of $\mathrm{Al}_{2} \mathrm{O}_{3}-\mathrm{TiO}_{2}$ showed poor performances in both: slightly and super oxidized flames due to their porosities were below $20 \%$. Additionally, in $\mathrm{ZrO}_{2}-\mathrm{Al}_{2} \mathrm{O}_{3}$ coatings the better cohesion between lamelles obtained in those sprayed with super oxidized flames increased their thermal shock resistance, because these flames allow a higher exposure time of particles in hottest zone of flame, getting a better melting.

In spite of their higher thermal shock resistance, the Ni-WC cermet top coatings, whose manufactured using a super oxidized flame evidenced a decreasing of their performance, which is related to oxidation of Ni produced from $600{ }^{\circ} \mathrm{C}$ in oxidizing environments, forming $\mathrm{NiO}$, whose thermal dilatation coefficient is lower than that for metallic nickel $\left(\alpha_{0}-900{ }^{\circ} \mathrm{C}=\right.$ $14,5^{*} 10^{-6} \mathrm{~K}^{-1}$ for $\mathrm{NiO}$ and $\alpha_{0}-900^{\circ} \mathrm{C}=17,6^{*} 10^{-6}$ $\mathrm{K}^{-1}$ for $\mathrm{Ni}$ ) decreasing the capacity of nickel to counteract the thermal stresses produced by mismatch in thermal dilatation between different materials constituting these coatings [16]. Additionally, the previous exposure to 100 cycles of heating-cooling from $650{ }^{\circ} \mathrm{C}$ decreased even more the thermal shock resistance of these coatings due to the extra oxidation produced in the nickel during thermal history (heating to $650{ }^{\circ} \mathrm{C}$ during 100 cycles).

It is important to notice that several samples showed failure in the interface between the substrate and bond coatings due to the degradation of substrate produced during thermal cycles (Figure 3a), without affecting the structural integrity of top coatings themselves (Figure 3b), independently of feedstock powder, flame and thickness used, which indicates that in these cases the top coatings are more resistant that the interfaces. However and particularly, this phenomenon occurred in all samples for Ni-WC cermet coatings cooled from $1100^{\circ} \mathrm{C}$, which indicates the great thermal shock resistance of these coatings compared with the other ones. Finally, the failure in the interface between substrates and bond coatings was due to the design of the samples, which only protect their cross section surface exposing the periphery uncoated of cylindrical specimens.

The thermal shock resistance for all samples tested from $650^{\circ} \mathrm{C}$ is higher than the 69 cycles before failure obtained by Wang [4] for $\mathrm{Al}_{2} \mathrm{O}_{3}-\mathrm{TiO}_{2}-\mathrm{ZrO}_{2}-\mathrm{CeO}_{2}$ and $\mathrm{Al}_{2} \mathrm{O}_{3}-13 \%$ wt. $\% \mathrm{TiO}_{2}$ coatings manufactured by plasma spray onto carbon steel substrates from nano-agglomerated, and from fused and crushed micrometrical particles respectively and tested in similar conditions [4].

For its part, the thermal shock resistance of all samples tested from $1100{ }^{\circ} \mathrm{C}$ is lower than the 83 cycles obtained by Z. Y. Pan [3] for $\mathrm{Al}_{2} \mathrm{O}_{3}, \mathrm{ZrO}_{2}$ stabilized with 8 wt. $\% \mathrm{Y}_{2} \mathrm{O}_{3}$, with additions of submicrometrical and nanometrical $\mathrm{SiC}$ particles, and manufactured by atmospheric plasma spray onto SUS 304 stainless steel substrates, using NiCoCrAlY as bond coat. However it is important to mention that Z.Y. Pan [3] evaluated the thermal shock resistance 
a)

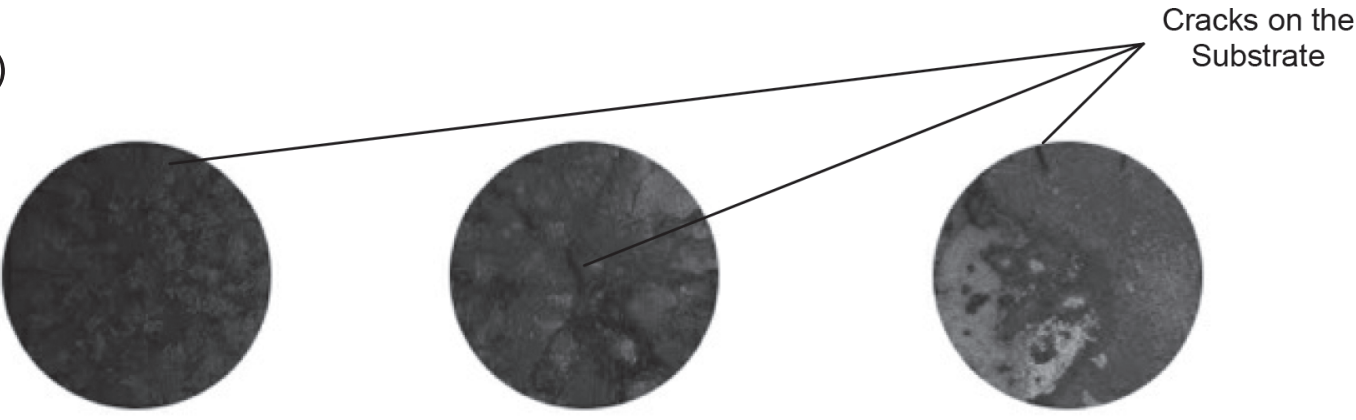

b)

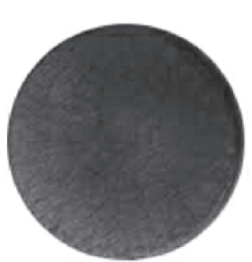

$\mathrm{Ni}-\mathrm{WC}$

Super oxidized flame Thickness low

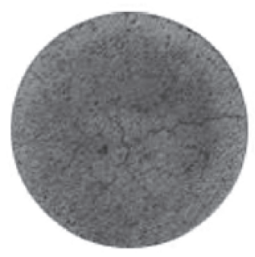

$\mathrm{Al}_{2} \mathrm{O}_{3}$

Slightly oxidized flame

Thickness low

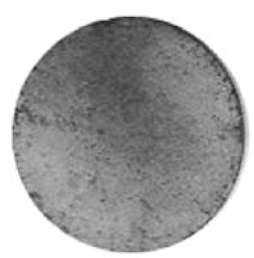

$\mathrm{Al}_{2} \mathrm{O}_{3}$

Slightly oxidized flame Thickness low

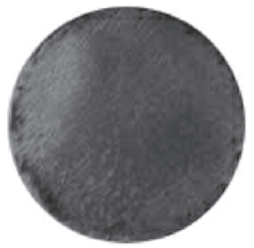

Ni-WC Super oxidized flame Thickness medium

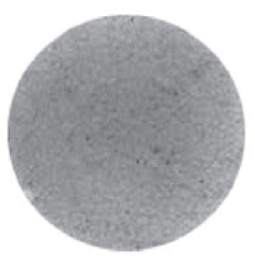

$\mathrm{ZrO}_{2}-\mathrm{Al}_{2} \mathrm{O}_{3}$ Slightly oxidized flame Thickness low

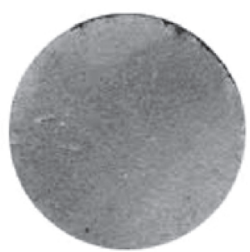

$\mathrm{ZrO}_{2}-\mathrm{Al}_{2} \mathrm{O}_{3}$ Slightly oxidized flame Thickness medium

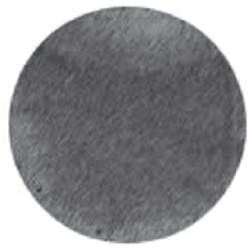

$\mathrm{Ni}-\mathrm{WC}$ Slightly oxidized flame Thickness high

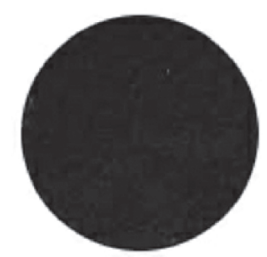

$\mathrm{Al}_{2} \mathrm{O}_{3}-\mathrm{TiO}_{2}$ Slightly oxidized flame Thickness low

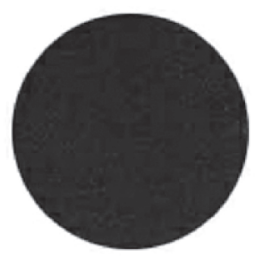

$\mathrm{Al}_{2} \mathrm{O}_{3}-\mathrm{TiO}_{2}$

Super oxidized flame Thickness high

Figure 3. Disbonding of coatings due to degradation of substrate. (a) Evidence of cracks on the surface of substrates producing detachment of coatings. (b) Top coatings detached in optimal conditions. 
cooling from $1000{ }^{\circ} \mathrm{C}$ and its failure criteria was the number of cycles before $20 \%$ of coating area exposed to thermal shock shows damage, which is less aggressive than the heat temperature of coatings and failure criteria used in this study.

On the other hand, in all samples the thermal shock resistance decreased slightly in thicker coatings, which is related to higher residual stresses in these specimens [15].

Finally, in statistical terms, it is important to notice that the assumptions of constant variance, normality and randomness of residuals for the DOE were accomplished successfully. Specifically, the factors: "Powder", "Flame" and "Thickness", as well as the interaction "Powder*Flame" are significant due to their $\mathrm{p}$-values in the ANOVA are $<0.05$. On the other hand, the interactions "Thickness*Flame" and "Thickness*Powder" are not significant (p-value $>0.05$ ) due to the small differences between the ranges of thickness obtained for the top coatings manufactured in this study. Particularly, the factor "Thickness" is relevant and the better performances were obtained with low thicknesses, which is aligned with the theory, which in turn says that low thicknesses favor the thermal shock resistance due to there is less likelihood to have cracks [17-19], and because the metal substrate has much higher fracture toughness than the ceramic coating, thus the thicker substrate provides stronger fracture prevention to the coating/substrate system [20].

\section{CONCLUSIONS}

Top coatings of Ni-WC (Cermet Eutectic Castolin $10112^{\mathrm{TM}}$ ) and $\mathrm{ZrO}_{2}-\mathrm{Al}_{2} \mathrm{O}_{3}$ (Eutectic Castolin $25088^{\mathrm{TM}}$ ), accompanied with bond coatings of Ni-Si (Eutectic Castolin CPM 1205 ${ }^{\mathrm{TM}}$ ) can be used successfully to coat flakes graphite cast iron molds used in the glass industry and fulfill the thermal shock resistance requirements that this industry requires due to any sample tested at the real operating temperature of molds $\left(650^{\circ} \mathrm{C}\right)$ showed failure.

Top coatings of $\mathrm{Ni}-\mathrm{WC}$ and $\mathrm{ZrO}_{2}-\mathrm{Al}_{2} \mathrm{O}_{3}$ showed the best performances against the thermal shock tests for both conditions: $1100{ }^{\circ} \mathrm{C}$ and $650{ }^{\circ} \mathrm{C} / 1100^{\circ} \mathrm{C}$. The thermo-elastic behavior of nickel matrix and the arrest crack effect characteristic of composite materials contributed with the good performance of coatings of Ni-WC. On the other hand, for coatings of $\mathrm{ZrO}_{2}-\mathrm{Al}_{2} \mathrm{O}_{3}$, the bimodal microstructures obtained also contributed with the good performance.

The best thermal shock resistance for both: Ni-WC and $\mathrm{ZrO}_{2}-\mathrm{Al}_{2} \mathrm{O}_{3}$ coatings was achieved with thin thicknesses of $139 \pm 4 \mu \mathrm{m}$, and with values of porosity between $20 \%$ and $40 \%$. Coatings below or above of these ranges of thicknesses and porosity showed poor performances.

\section{ACKNOWLEDGEMENTS}

Universidad de Antioquia - Grupo de Investigaciones Pirometalúrgicas y de Materiales (GIPIMME), Estrategia de Sostenibilidad CODI 2014-2015. Universidad de Antioquia - Grupo de Investigación en Materiales y Recubrimientos Cerámicos (GIMACYR). Owens-Illinois Inc. Envigado and Buga Plants - Colombia - Department of Engineering.

\section{REFERENCES}

[1] J.L. Lee and S.C. Lee. "Thermal Fracture Endurance of Cast Irons with Application Study of Pig Iron Ingot Molds". Metall. Trans. Vol. 26, Issue 6, pp. 1431-1440. June, 1995.

[2] H.J. Kim and Y.-G. Kweon. "The Application of Thermal Sprayed Coatings for Pig Iron Ingot Molds". Journal of Thermal Spray Technology. Vol. 5, Issue 4, pp. 463-468. December, 1996.

[3] Z.Y. Pan, Y. Wang, C.H. Wang, X.G. Sun and L. Wang. "The Effect of SiC particles on Thermal Shock Behavior of $\mathrm{Al}_{2} \mathrm{O}_{3} / 8 \mathrm{YSZ}$ Coatings Fabricated by Atmospheric Plasma Spraying". Surface and Coatings Technology. Vol. 206, Issue 8-9, pp. 2484-2498. January, 2012.

[4] Y. Wang, W. Tian and Y. Yang. "Thermal Shock behavior of nanostructured and conventional $\mathrm{Al}_{2} \mathrm{O}_{3} / 13$ wt $\% \mathrm{TiO}_{2}$ coatings fabricated by plasma spraying". Surface and Coatings Technology. Vol. 201, Issue 18, pp. 7746-7754. June, 2007.

[5] ASTM A247-10. "Standard Test Method for Evaluating the Microstructure of Graphite in Iron Castings". ASTM International. West Conshohocken, PA, USA. 2010. URL: www. astm.org.

[6] P. Fauchais, J. Heberlein and M. Boulos. "Thermal Spray Fundamentals From 
Powder to Part". Springer. First Edition. New York, USA, pp. 1566. 2014. ISBN: 978-0-387-28319-7.

[7] Linde Catalogue. "Acetylene fuel gas for Oxyfuel gas processes". Linde AG. Munich, Germany. February, 2010.

[8] ASTM E1920-03. "Standard Guide for Metallographic Preparation of Thermal Sprayed Coatings". 2008.

[9] ASTM E2109-01. "Test Methods for Determining Area Percentage Porosity in Thermal Sprayed Coatings". 2007.

[10] O-IGlobal Engineering Team. "MoldEquipment at O-I. Metallurgical Considerations". O-I. First Edition. Perrysburg, USA. January, 1974.

[11] P. Fauchais. "Powders to Thermally Sprayed Coatings. Journal of Thermal Spray Technology”. Vol. 19, Issue 1-2, pp. 56-80. January, 2010.

[12] C. Zhai, J. Wang, F. Li, J. Tao, Y. Yang and B. Sun. "Thermal shock properties and failure mechanism of sprayed $\mathrm{Al}_{2} \mathrm{O}_{3} /$ $\mathrm{TiO}_{2}$ nanocomposite coatings". Ceramics International. Vol. 31, pp. 817-824. December, 2004.

[13] Q. Yu, A. Rauf, N. Wang and C. Zhou. "Thermal properties of plasma-sprayed thermal barrier coating with bimodal structure". Ceramics International. Vol. 37, pp. 1093-1099. December, 2010.
[14] G. Girolamo, F. Marra, C. Blasi, E. Serra and T. Valente. "Microstructure, mechanical properties and thermal shock resistance of plasma sprayed nanostructured zirconia coatings". Ceramics International. Vol. 37, pp. 2711-2717. April, 2011.

[15] S. Rangaswamy, H. Herman, S. Safai. "Thermal expansion study of plasma sprayed coatings". Thin Solid Films. Vol. 73, pp. 43-52. 1980.

[16] H. Fujiwara. "Residual Stresses-III. Science and Technology. Elsevier Science Publishers LTD”. First Edition, Tukushima, Japan, pp. 1525. 1990. ISBN: 978-1-851-66857-1.

[17] L. Pawlowski. "The Science and Engineering of Thermal Spray Coatings". John Wiley \& Sons. Second Edition, pp. 626. Chichenster, England. ISBN: 978-0-471-49049-4. 2008.

[18] J. Han and B. Wang. "Thermal shock resistance enhancement of functionally graded materials by multiple cracking". Acta Materialia. Vol. 54, pp. 963-973. December, 2005.

[19] J. Han. "Thermal shock resistance of ceramic coatings". Acta Materialia. Vol. 55, pp. 35733581. March, 2007.

[20] B. Wang, J. Han and S. Du. "Thermal shock resistance analysis methodology of ceramic coating/metal substrate systems". Engineering Fracture Mechanics. Vol. 77, pp. 939-950. February, 2010. 